\title{
Growth, yield and nutrient uptake of hybrid rice as influenced by nutrient management modules and its impact on economic of the treatments
}

\author{
Ashish Kumar Srivastava ${ }^{1}$ and Anil Kumar Singh ${ }^{2 *}$ \\ ${ }^{1}$ Department of Soil Science, Narendra Deva University of Agriculture and Technology, (Narendra Nagar) Kumar- \\ ganj, Faizabad-224 229 (Uttar Pradesh), INDIA \\ ${ }^{2}$ Corresponding author: Present address: Assistant Professor, SMM Town PG College, Ballia- 277001, (U.P.), \\ INDIA \\ *Corresponding author. E-mail: singhani180@gmail.com
}

Received: December 21, 2016; Revised received: July 2, 2017; Accepted: November 5, 2017

\begin{abstract}
Field experiment was conducted at Instructional Farm of Narendra Deva University of Agriculture and Technology, Kumarganj, Faizabad to develop nutrient management modules for efficient cultivation of hybrid rice. Results showed that growth and yield characters viz. plant height, number of tilers and panicles per hills were highest under nutrient management module of $100 \%$ NPK +5 t pressmud $\left(T_{3}\right)$. Significantly higher grain and straw yield was recorded under treatment $T_{3}$ over all the treatment except treatment $T_{1}, T_{2}, T_{4}, T_{5}$ and $T_{6}$ which were recorded on par. Uptake of NPKS and Zn was significantly improved under treatments having organic manure along with inorganic levels $(100 \%, 75 \%$ and $50 \%$ NPK) of fertilizer over alone levels of inorganic fertilizer. NPKS and Zn uptake was higher in treatment module $T_{3}$ followed by treatment $T_{2}\left(100 \%\right.$ NPK +10 t FYM ha $\left.{ }^{-1}\right)$. The net return Rs. $27373.70 \mathrm{ha}^{-1}$ and $26087.0 \mathrm{ha}^{-1}$ and benefit: cost ratio (1.53 and 1.45) was maximum in treatment $\mathrm{T}_{3}$ closely followed by $T_{2}$. Findings of this study warranted that treatment module $\mathrm{T}_{3}$ resulted higher growth and yield of rice crop. Net return was also higher in this treatment.
\end{abstract}

Keywords: Economic of treatments, Growth, Hybrid rice, Nutrient management modules, Nutrients uptake, Yield

\section{INTRODUCTION}

India ranks first in acreage and second in rice production only after China. Rice is India's predominant crop and the staple food of the eastern and southern part of the country (Prabakaran and Sivapragasam, 2014 and Singh et al., 2012). During the year 2013-2014, India produced 106.65 million tonnes rice from 44.13 million hectare area (Anonymous, 2015-16). Hybrid rice possessed 10 to 15 per cent yield advantage over inbred varieties due to more vigorous and extensive root system (Young et al., 1999) increased growth rate during vegetative stage (Yamauchi, 1994), more efficient sink formation, faster rate of translocation of photosynthates and greater sink size (Kabaki, 1993). However, high productivity of hybrid rice cannot be sustained unless the declining trend in soil fertility resulting from the huge nutrient removal by hybrid rice is replenished properly through integrated nutrient management practices (Singh, 2013).

Diverse organic sources including farmyard manure (FYM), pressmud, water hyacinth, green manure and blue green algae (BGA) are available for use in agriculture. Conjunctive use of organic nutrients along with chemical fertilizers provides an opportunity to attain long term sustainability in crop production system without deterioration of land (Reddy, 2000).
Hence, selection of proper variety and adoption of advanced agronomic practices could play an important role in increasing productivity (Singh et al., 2008). The use of local bio-degradable, non-toxic and cost effective agro waste can be well affordable for the Indian agrarian (Ashok et al, 2015). Keeping in view the above facts, the present study was, therefore, carried out to develop effective nutrient management modules for sustaining productivity of hybrid rice and increasing profitability by use of locally available resources.

\section{MATERIALS AND METHODS}

The research study was carried out on the field of Instructional Farm of Narendra Deva University of Agriculture and Technology, Kumarganj, Faizabad (U.P.) during kharif 2004-05 and 2005-06 to find out the effect of nutrient management modules on growth, yield, nutrients uptake of hybrid rice and economic feasibility of the various treatments. The experimental site falls under subtropical zone in Indo-Gangetic plains having alluvial calcareous soil and lies between latitude $26.47^{\circ}$ north and at longitude $82.12^{\circ}$ east with elevation of about $113 \mathrm{~m}$ from sea level. The experiment comprised of eighteen treatments module viz. $\mathrm{T}_{1}$ (100\% NPK), $\mathrm{T}_{2}(100 \% \mathrm{NPK}+10 \mathrm{t} \mathrm{FYM}), \mathrm{T}_{3}(100 \%$ $\mathrm{NPK}+5 \mathrm{t}$ pressmud $), \mathrm{T}_{4}(100 \% \mathrm{NPK}+5 \mathrm{t}$ water hya- 
cinth), $\mathrm{T}_{5}(100 \% \mathrm{NPK}+5 \mathrm{t}$ green manure $), \mathrm{T}_{6}(100 \%$ $\mathrm{NPK}+10 \mathrm{~kg} \mathrm{BGA} \mathrm{Crust}), \mathrm{T}_{7}(75 \%, \mathrm{NPK}), \mathrm{T}_{8}(75 \%$ $\mathrm{NPK}+10 \mathrm{t}$ FYM $), \mathrm{T}_{9}(75 \% \mathrm{NPK}+5 \mathrm{t}$ pressmud $), \mathrm{T}_{10}$ $\left(75 \% \mathrm{NPK}+5 \mathrm{t}\right.$ water hyacinth), $\mathrm{T}_{11}(75 \% \mathrm{NPK}+5 \mathrm{t}$ green manure), $\mathrm{T}_{12}(75 \% \mathrm{NPK}+10 \mathrm{~kg}$ BGA crust ha $\left.{ }^{1}\right), \mathrm{T}_{13}\left(50 \% \operatorname{NPK}\left(75: 37.5: 37.5 \mathrm{NPK} \mathrm{kg} \mathrm{ha}{ }^{-1}\right), \mathrm{T}_{14}\right.$ $(50 \% \mathrm{NPK}+10 \mathrm{t}+\mathrm{FYM}), \mathrm{T}_{15}(50 \% \mathrm{NPK}+5 \mathrm{t}$ pressmud), $\mathrm{T}_{16}(50 \% \mathrm{NPK}+5 \mathrm{t}$ water hyacinth $), \mathrm{T}_{17}$ $\left(50 \% \mathrm{NPK}+5 \mathrm{t}\right.$ green manure) and $\mathrm{T}_{18}(50 \% \mathrm{NPK}+$ $10 \mathrm{~kg}$ BGA crust) and tested in a randomized block design and replicated three times. To lay out the experiment field was divided into plots of $5 \mathrm{~m} \mathrm{x} 4 \mathrm{~m}$ by providing $30 \mathrm{~cm}$ high and $50 \mathrm{~cm}$ wide bunds all around each plot. The treatments to the plots were allotted randomly and incorporated uniformly in the soil. FYM and pressmud was incorporated uniformly in the plots 7 days before transplanting of rice to the depth of 10 $15 \mathrm{~cm}$. However, water hyacinth was applied in the field 15 days before transplanting. Treated plots were left for 15 days in order to facilitate the complete decomposition of water hyacinth. Dhaincha (Sesbania aculeata) was collected from the outside field. The Sesbania green manure crop was cut down after chopping with the help of sickle and it was incorporated in to the field according to treatment in to the top $15 \mathrm{~cm}$ soil one week before of rice transplanting. BGA crust was incorporated uniformly in the plots 20 days after transplanting of rice crop. Full dose of phosphorus and potassium and half dose of nitrogen were applied as basal while remaining half dose of nitrogen was applied in two equal splits at tillering and panicle initiation stages. A common dose of zinc sulphate @ $25 \mathrm{~kg}$ $\mathrm{ha}^{-1}$ was applied at the time of transplanting. Transplanting was done manually at $20 \mathrm{~cm} \mathrm{x} 15 \mathrm{~cm}$ distance using one seedling per hill. A thin film of water (2-3 $\mathrm{cm}$ ) was maintained during the initial stage of seedling establishment. Thereafter, crop was irrigated as and when required to maintain the water level. Weeds were removed manually at 20 and 40 days after transplanting. The plant height was measured at harvest stage on three hills located at different places in the plot with the help of a meter scale from base of the plant to the tip of the tallest plant part. The number of panicles per hills was counted randomly from the selected five hills. Length of five panicles was measured randomly in each plot with the help of meter scale at maturity. Five panicles from each plot were taken randomly at maturity stage for counting the number of spikelets per panicle. Three panicles from each plot were taken randomly at maturity stage for counting the number of grains per panicle and averaged. After taking the bundles weight of the harvested produce of each net plot, their grains were separated manually. The grain yield was recorded at 14 per cent moisture from each net plot after threshing and the values were converted to $\mathrm{q}$ $\mathrm{ha}^{-1}$. Random grain samples were collected from the produce of each net plot and 1000 grains were counted and weighed with the help of electronic balance to obtain test weight. Harvest index of each experimental plot was calculated considering both grain and straw yield. Modified Kjeldahl's method was followed for determination of $\mathrm{N}$ content in plant and grain samples as described by (Jackson, 1973). P content was determined in the digested plant material by vanadomolybdate phosphoric yellow colour method as described by Jackson (1973). K was determined by flame photometer (Jackson, 1973). S content was determined by turbidimetric method as described by Chesnin and Yein (1951). Zn content in plants and grains was determined on atomic absorption spectrophotometer by using zinc hollow cathode lamp (Lindsey and Narwell, 1978). The nutrient uptake by grain and straw of rice crop were calculated in relation to dry matter production and their nutrient contents. The cost of cultivation was worked out by the considering expenses incurred due to treatment cost and common cost. The experimental data were analyzed using "Analysis of variance" in randomized block design. The critical differences at 5 per cent level of probability were calculated for testing the significance of difference between any two means whereas ' $F$ ' test was significant (Snedecor and Cochran, 1967).

\section{RESULTS AND DISCUSSION}

Growth and yield attributing characters: The plant height as affected by different treatment combinations given in Table 1. The significant difference was observed in plant height due to different organic and inorganic fertilizer treatments. Significantly higher plant height was recorded under all the treatments over treatment $50 \%$ NPK alone. The highest plant height was measured in the treatment $\mathrm{T}_{3}$. The increase in plant height might be due to stimulation of cell, elongation, division and enlargement as reported by Thukral et al. (1994). Parasuraman (2005) also observed that integrated use of $\mathrm{N}$ fertilizer with Dhaincha found to be favourably affect the growth and yield attributes such as plant height and total dry matter production in rice crop.

The number of tillers and panicles hill ${ }^{-1}$ are the most important yield attributing characters. Influence of

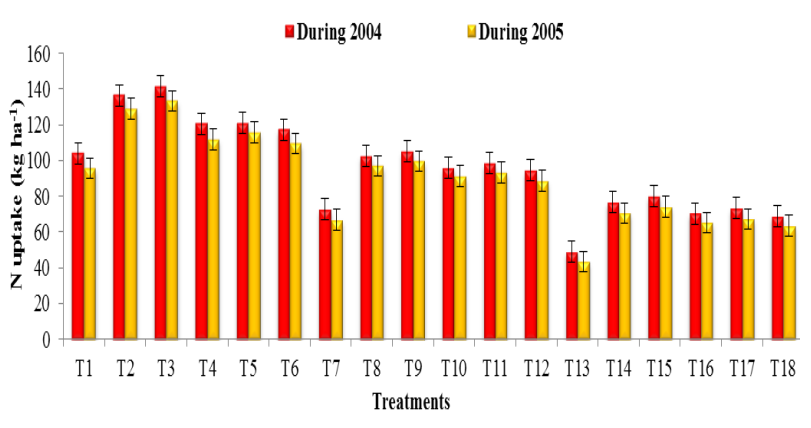

Fig. 1. Effect of nutrient management modules on $N$ uptake by hybrid rice crop. 
Ashish Kumar Srivastava and Anil Kumar Singh / J. Appl. \& Nat. Sci. 9 (4): 2414 - 2420 (2017)
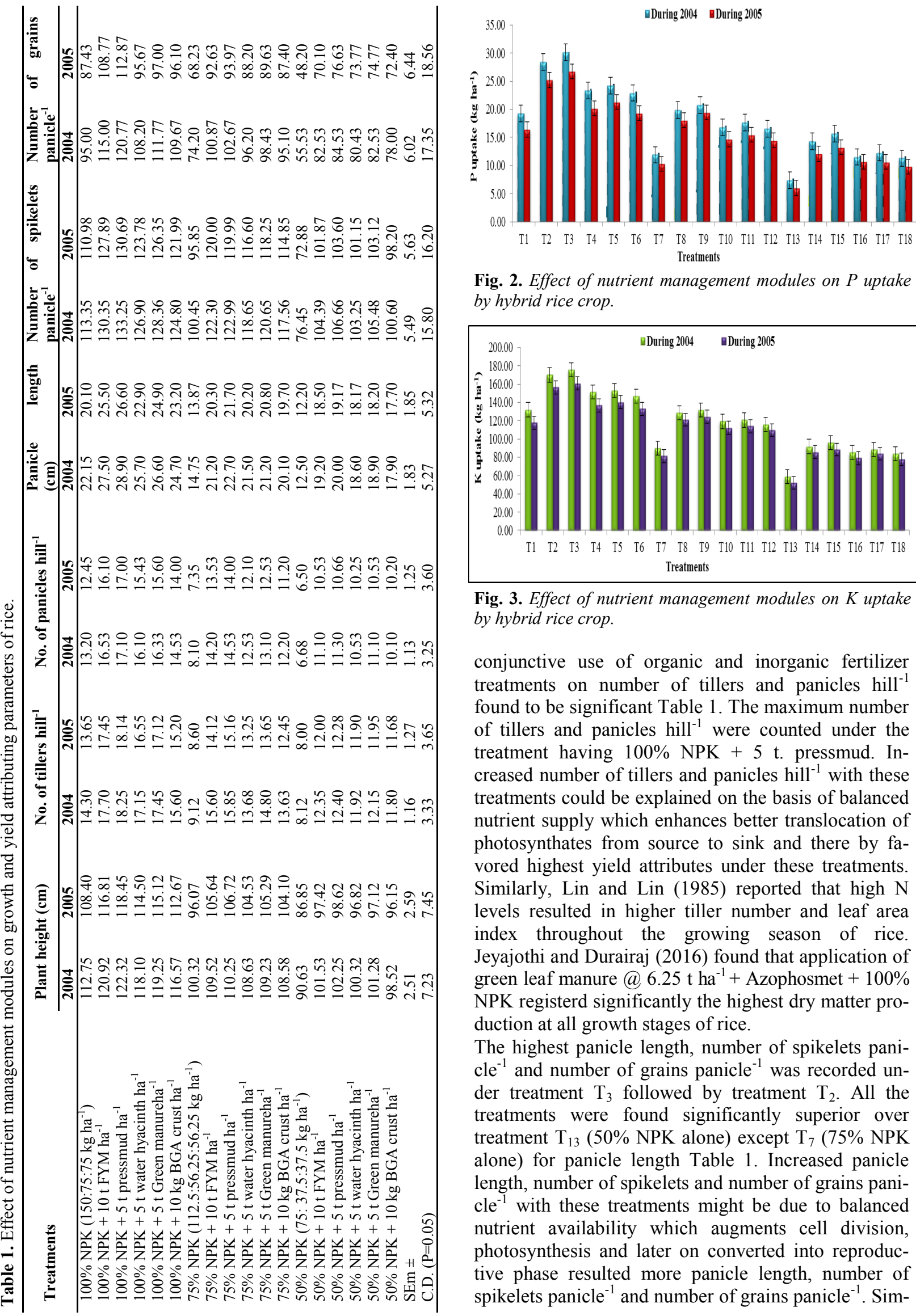

Fig. 2. Effect of nutrient management modules on P uptake by hybrid rice crop.

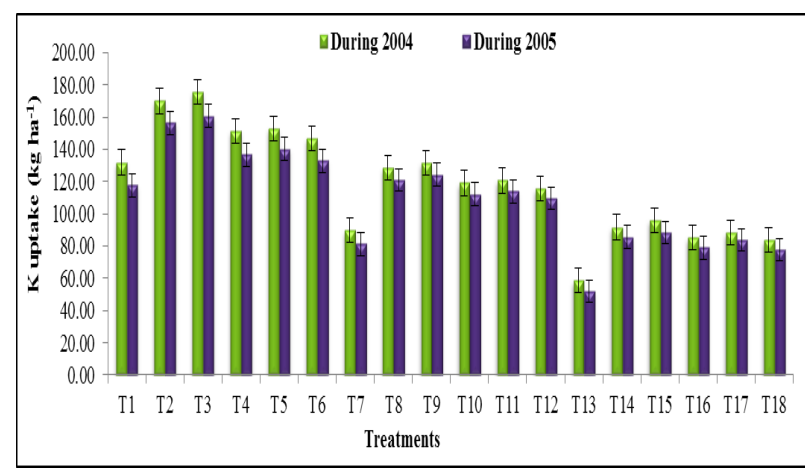

Fig. 3. Effect of nutrient management modules on $K$ uptake by hybrid rice crop.

conjunctive use of organic and inorganic fertilizer treatments on number of tillers and panicles hill ${ }^{-1}$ found to be significant Table 1. The maximum number of tillers and panicles hill ${ }^{-1}$ were counted under the treatment having $100 \%$ NPK +5 t. pressmud. Increased number of tillers and panicles hill ${ }^{-1}$ with these treatments could be explained on the basis of balanced nutrient supply which enhances better translocation of photosynthates from source to sink and there by favored highest yield attributes under these treatments. Similarly, Lin and Lin (1985) reported that high N levels resulted in higher tiller number and leaf area index throughout the growing season of rice. Jeyajothi and Durairaj (2016) found that application of green leaf manure @ $6.25 \mathrm{t} \mathrm{ha}^{-1}+$ Azophosmet + 100\% NPK registerd significantly the highest dry matter production at all growth stages of rice.

The highest panicle length, number of spikelets pani$\mathrm{cle}^{-1}$ and number of grains panicle ${ }^{-1}$ was recorded under treatment $T_{3}$ followed by treatment $T_{2}$. All the treatments were found significantly superior over treatment $\mathrm{T}_{13}\left(50 \%\right.$ NPK alone) except $\mathrm{T}_{7}$ (75\% NPK alone) for panicle length Table 1. Increased panicle length, number of spikelets and number of grains pani$\mathrm{cle}^{-1}$ with these treatments might be due to balanced nutrient availability which augments cell division, photosynthesis and later on converted into reproductive phase resulted more panicle length, number of spikelets panicle $^{-1}$ and number of grains panicle ${ }^{-1}$. Sim- 
Table 2. Effect of nutrient management modules on yield, harvest index and test weight of rice.

\begin{tabular}{|c|c|c|c|c|c|c|}
\hline \multirow{2}{*}{ Treatments } & \multicolumn{2}{|c|}{ Grain yield $\left(\mathrm{q} \mathrm{ha}^{-1}\right)$} & \multicolumn{2}{|c|}{ Harvest index } & \multicolumn{2}{|c|}{ Test weight (g) } \\
\hline & 2004 & 2005 & 2004 & 2005 & 2004 & 2005 \\
\hline $100 \%$ NPK $\left(150: 75: 75 \mathrm{~kg} \mathrm{ha}^{-1}\right)$ & 56.72 & 53.25 & 44.44 & 44.24 & 22.90 & 22.60 \\
\hline $100 \%$ NPK +10 t FYM ha $^{-1}$ & 68.55 & 65.63 & 44.64 & 44.44 & 23.40 & 23.40 \\
\hline $100 \%$ NPK +5 t pressmud ha ${ }^{-1}$ & 70.15 & 67.12 & 44.84 & 44.84 & 23.60 & 23.50 \\
\hline $100 \%$ NPK +5 t water hyacinth ha ${ }^{-1}$ & 62.85 & 59.46 & 44.31 & 44.44 & 23.40 & 23.10 \\
\hline $100 \%$ NPK +5 t Green manureha ${ }^{-1}$ & 63.00 & 60.70 & 44.20 & 44.24 & 23.40 & 23.20 \\
\hline $100 \%$ NPK $+10 \mathrm{~kg} \mathrm{BGA} \mathrm{crust} \mathrm{ha}{ }^{-1}$ & 61.80 & 58.70 & 44.27 & 44.24 & 23.10 & 23.00 \\
\hline 75\% NPK (112.5:56.25:56.25 $\left.\mathrm{kg} \mathrm{ha}^{-1}\right)$ & 42.50 & 40.00 & 44.05 & 43.85 & 22.15 & 22.00 \\
\hline $75 \%$ NPK + 10 t FYM ha-1 & 55.55 & 53.85 & 44.24 & 44.05 & 22.70 & 22.50 \\
\hline $75 \%$ NPK +5 t pressmud ha ${ }^{-1}$ & 56.32 & 54.46 & 44.44 & 44.25 & 22.70 & 22.70 \\
\hline $75 \%$ NPK $+5 \mathrm{t}$ water hyacinth $\mathrm{ha}^{-1}$ & 53.90 & 52.00 & 43.86 & 43.66 & 22.50 & 22.40 \\
\hline $75 \%$ NPK +5 t Green manureha ${ }^{-1}$ & 54.58 & 52.80 & 44.24 & 44.05 & 22.60 & 22.40 \\
\hline $75 \%$ NPK $+10 \mathrm{~kg} \mathrm{BGA} \mathrm{crust} \mathrm{ha-}{ }^{-1}$ & 53.10 & 51.35 & 44.05 & 43.86 & 22.40 & 22.17 \\
\hline $50 \%$ NPK $\left(75: 37.5: 37.5 \mathrm{~kg} \mathrm{ha}^{-1}\right)$ & 30.25 & 27.10 & 42.73 & 42.55 & 20.50 & 20.97 \\
\hline $50 \%$ NPK +10 t FYM ha $^{-1}$ & 43.55 & 40.65 & 43.29 & 43.10 & 21.23 & 21.90 \\
\hline $50 \%$ NPK $+5 \mathrm{t}_{\text {pressmud }} \mathrm{ha}^{-1}$ & 44.80 & 41.80 & 43.47 & 43.29 & 21.77 & 22.00 \\
\hline $50 \%$ NPK $+5 \mathrm{t}$ water hyacinth $\mathrm{ha}^{-1}$ & 41.85 & 39.70 & 43.10 & 42.91 & 21.80 & 21.60 \\
\hline $50 \%$ NPK $+5 t_{\text {Green manureha }}^{-1}$ & 42.70 & 40.20 & 42.91 & 42.73 & 21.80 & 21.70 \\
\hline $50 \% \mathrm{NPK}+10 \mathrm{~kg} \mathrm{BGA}$ crust ha ${ }^{-1}$ & 41.00 & 38.65 & 42.73 & 42.56 & 21.70 & 21.60 \\
\hline $\mathrm{SEm} \pm$ & 3.56 & 3.61 & - & - & 0.40 & 0.46 \\
\hline C.D. $(\mathrm{P}=0.05)$ & 10.25 & 10.41 & - & - & 1.15 & 1.32 \\
\hline
\end{tabular}

ilarly, Singh (2013) reported that combined use of organic with inorganic fertilizers helped in increasing crop growth, physiological parameters viz. chlorophyll content and leaf area index, yield attributing characters such as panicle length, panicle weight and yield of the hybrid rice.

Grain yield: The grain yield of hybrid rice was significantly influenced by various nutrient management modules (Table 2) (). Maximum grain yield (70.15 q ha ${ }^{-1}$ and $67.12 \mathrm{q} \mathrm{ha}^{-1}$ ) of rice crop was recorded under nutrient management module $T_{3}$ followed by $T_{2}$. Significantly higher grain yield was recorded under treatment having $100 \%$ NPK $+5 \mathrm{t}$ pressmud over all the treatment except treatment $\mathrm{T}_{1}, \mathrm{~T}_{2}, \mathrm{~T}_{4}, \mathrm{~T}_{5}$ and $\mathrm{T}_{6}$ which were recorded on par. Among the various nutrient management modules application of $5 \mathrm{t}$ pressmud ha ${ }^{-1}$ found to be most superior at $100 \%$ NPK, $75 \%$ NPK as well as 50\% NPK levels considering the grain yield of hybrid rice. The increase in grain yield might be due to improved yield attributes, morphological and biological characters and better translocation of photosyn-

घDuring 2004 DDuring 2005

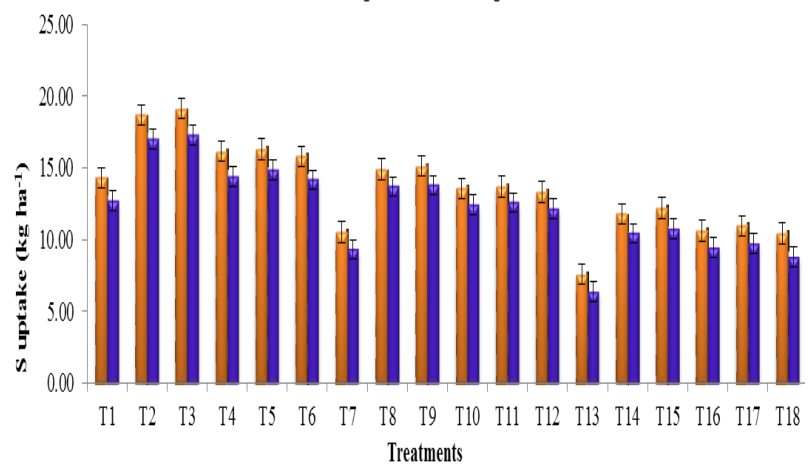

Fig. 4. Effect of nutrient management modules on S uptake by hybrid rice crop. thates from source to sink. Superior crop growth was observed in pressmud treated plot might be due to its effectiveness in the improvement of physical as well as chemical properties of the soil and providing good environment to plant. Similarly, Singh (2014a ) reported highest yield of hybrid rice from plot treated with $75 \% \mathrm{RDF}+$ green manure along with $40 \mathrm{~kg}$ zinc sulphate $\mathrm{ha}^{-1}$. Kumar et al (2001) observed maximum rice grain and straw yield with $100 \% \mathrm{NPK}+20 \mathrm{t}$. FYM $+10 \mathrm{~kg} \mathrm{BGA} \mathrm{ha}{ }^{-1}$

Test weight and harvest index: Data pertaining to the effect of nutrient management modules on test weight and harvest index revealed that highest test weight and harvest index was found under the treatment $T_{3}$, while the lowest test weight was recorded in treatment $T_{13}$ (50\% NPK alone) Table 2. The harvest index of hybrid rice was higher (44.29) in the integrated application of nutrients (75\% RDF + green manuring) as compared to the sole application of either organic or inorganic source of nutrient Singh (2014b).

Nitrogen uptake: Data with respect toN uptake by aDuring 2004 aDuring 2005

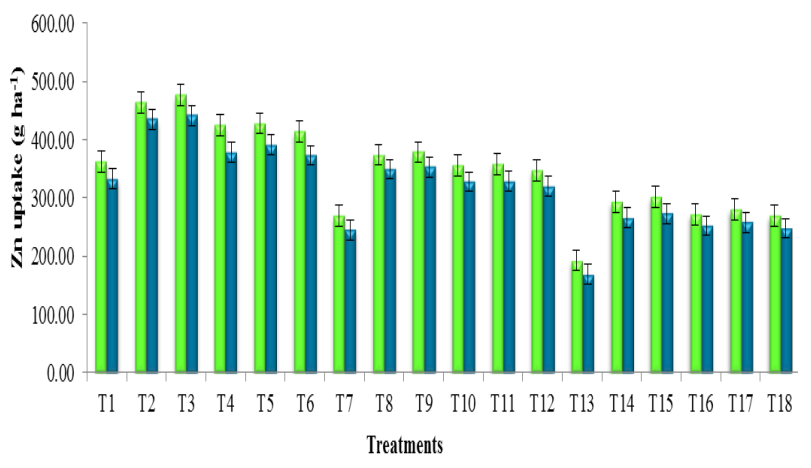

Fig. 5. Effect of nutrient management modules on Zn uptake by hybrid rice crop. 
Ashish Kumar Srivastava and Anil Kumar Singh / J. Appl. \& Nat. Sci. 9 (4): 2414 - 2420 (2017)

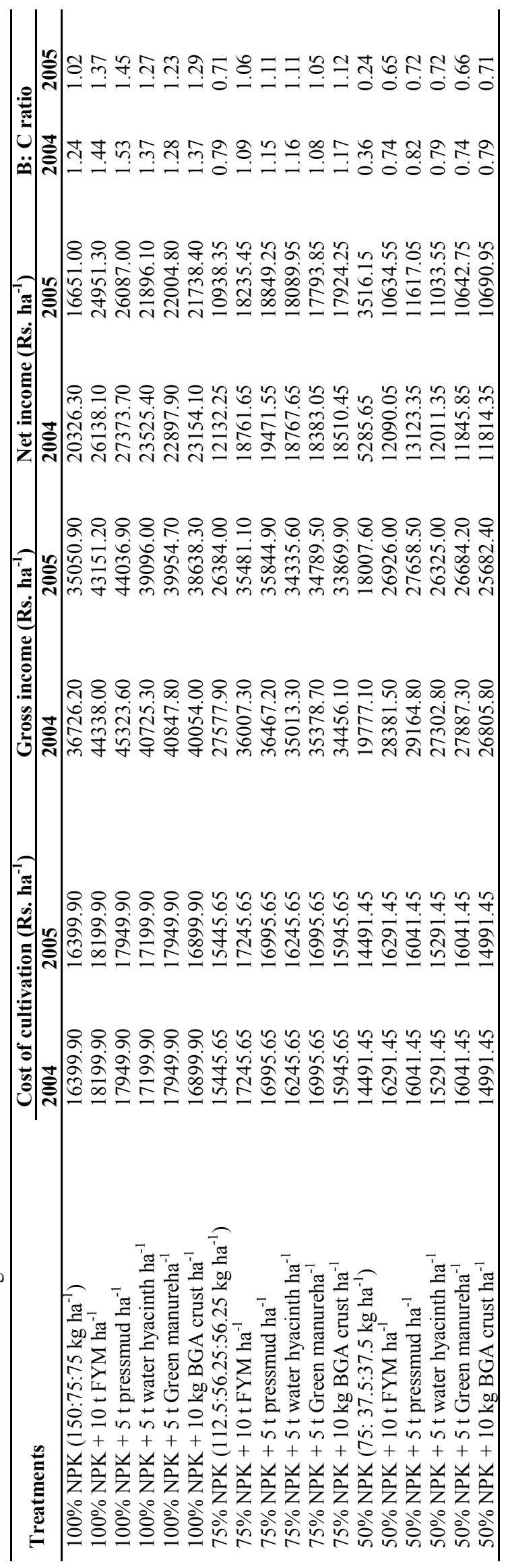

rice indicates that significant improvement in $\mathrm{N}$ uptake was noticed under treatments consisting organic manure along with $100 \%, 75 \%$ and $50 \%$ NPK over $100 \%$, $75 \%$ and $50 \%$ NPK alone (Fig. 1). The enhanced N uptake in these treatments might be due to adequate $\mathrm{N}$ availability in soil which increases the $\mathrm{N}$ absorption by the plants and ultimately increases the $\mathrm{N}$ content in grain and straw and total biological yield affected the N uptake. Similarly, Singh (2014a) reported higher N uptake under conjunctive use of organic and inorganic fertilizers in hybrid rice.

Phosphorus uptake: $P$ uptake increased with increasing level of NPK and addition of organic manure like FYM, pressmud, water hyacinth, green manure and BGA. The maximum uptake of phosphorus $(30.13 \mathrm{~kg}$ $\mathrm{ha}^{-1}$ and $26.72 \mathrm{~kg} \mathrm{ha}^{-1}$ ) was estimated in treatment $\mathrm{T}_{3}$, while least $\left(7.33 \mathrm{~kg} \mathrm{ha}^{-1}\right.$ and $\left.6.01 \mathrm{~kg} \mathrm{ha}^{-1}\right)$ with treatment $\mathrm{T}_{13}(50 \%$ NPK alone) Fig. 2. This may be due to formation of weak acids during decomposition of organic manure which helps to convert the complex forms of phosphorus in to soluble form. Availability of phosphorus increases its content in plants and total biological yield, which ultimately increases the phosphorus uptake. Kumar et al. (2001) reported that nutrients uptake (N, P, K, S and Zn) decrease with the reduction in levels of inorganic fertilizers either alone or in combination eith FYM and BGA.

Potassium uptake: The $\mathrm{K}$ uptake as affected by different nutrient management modules have been presented in Fig.3. Maximum K uptake (175.62 and $160.70 \mathrm{~kg} \mathrm{ha}^{-1}$ ) was observed in treatment $\mathrm{T}_{3}$, while minimum $\left(58.58 \mathrm{~kg} \mathrm{ha}^{-1}\right.$ and $\left.52.03 \mathrm{~kg} \mathrm{ha}^{-1}\right)$ in treatment $\mathrm{T}_{13}$ during respective years Fig. 3. The availability of $\mathrm{K}$ was increased might be due to application of potassic fertilizer as well as by application of organic manures. Sharma and Sharma (2002) observed that integrated application of NPK +FYM in rice crop increased uptake of N 30-45, P 7-10 and K 25-42 kgha ${ }^{-1}$. Sulphur and Zinc uptake: The nutrient management modules systems affected the $\mathrm{S}$ and $\mathrm{Zn}$ uptake by the crop. Highest $\mathrm{S}$ uptake noticed in treatment $\mathrm{T}_{3}$. Application of FYM and pressmud along with $100 \%, 75 \%$ and $50 \%$ NPK increases the S uptake significantly over alone application of $100 \%, 75 \%$ and $50 \%$ NPK Fig. 4. The increase in $\mathrm{S}$ uptake by the crop of rice might be because of increase in their content in grains and straw as well as total biological yield because uptake is the product of biological yield and concentration of nutrients. Further it is evident by the fig. 5 that maximum $\mathrm{Zn}$ uptake was recorded under treatment $\mathrm{T}_{3}$. Application of organic manure (FYM, pressmud, water hyacinth, green manure and BGA) along with $100 \%, 75 \%$ and $50 \%$ NPK significantly increase $\mathrm{Zn}$ uptake over $100 \%, 75 \%$ and $50 \%$ NPK alone treatments. Increased uptake of $\mathrm{Zn}$ by rice crop with application of organic manure and increase in NPK doses may be attributed to the adequate supply of this nutri- 
ent, its content in grain, straw and total biomass. Singh (2014a) reported highest $\mathrm{Zn}$ uptake (418.46 $\mathrm{g} \mathrm{ha}^{-1}$ and $424.32 \mathrm{~g} \mathrm{ha}^{-1}$ ) with $75 \% \mathrm{RDF}+$ green manuring. Similarly, Rabeya Khaman et al. (1997) observed that the application of organic manure and bio-fertilizers in addition to the recommended dose of fertilizers produced significantly higher uptake of N, P, K, Ca and S by the rice crop.

Economic feasibility of various nutrient management modules: Results revealed that maximum cost of cultivation (Rs. $18199.90 \mathrm{ha}^{-1}$ ) was recorded in treatment $T_{2}$ followed by treatment $T_{3}$ and $T_{5}$ (17949.90 ha $\mathrm{ha}^{-1}$ ), while minimum cumulative cost of cultivation was incurred (Rs. $14491.45 \mathrm{ha}^{-1}$ ) was in treatment $T_{13}$. In respect to economic feasibility the highest net return, and benefit cost ratio (Rs. 27373.70 $\mathrm{ha}^{-1}$ and Rs. $\left.26087.00 \mathrm{ha}^{-1}\right)$ and (1.53 and 1.45) was computed under the treatment $T_{3}$ in respective years Table 3. However, minimum net return (Rs. 5285.65 $\mathrm{ha}^{-1}$ and $\left.3516.15 \mathrm{ha}^{-1}\right)$ and benefit cost ratio $(0.36$ and 0.24 ) was calculated under treatment $T_{13}$, respectively. The net return and benefit cost ratio increased due to low cost of cultivation and higher yield of rice crop under treatment $\mathrm{T}_{3}$ followed by $\mathrm{T}_{2}$. Swaroopa et al. (2016) reported that the cultivation of paddy under improved technology viz. use of high yielding variety, seed treatment, adequate supply of fertilizers and applying scientific practices in plant protection measure and weed management practices gave higher net return compared to farmer practices. Similarly, Singh (2014b) in a study on hybrid rice observed highest net return under plot receiving $75 \% \mathrm{RDF}+$ green manure with $40 \mathrm{~kg}$ zinc sulphate $\mathrm{ha}^{-1}$

\section{Conclusion}

In the light of results obtained in present investigation it may be concluded that treatment module of $100 \%$ $\mathrm{NPK}+5 \mathrm{t}$ pressmud $\mathrm{ha}^{-1}$ resulted higher growth and grain yield (70.15 and $67.12 \mathrm{q} \mathrm{ha}^{-1}$ ) of hybrid rice crop. Application of FYM and pressmud along with $50 \%, 75 \%$ and $100 \%$ NPK improved uptake of nutrients (NPKS and $\mathrm{Zn}$ ) significantly over $50 \%, 75 \%$ and $100 \%$ NPK alone. Similarly maximum net return (Rs. 27373.70 and Rs. $26087.00 \mathrm{ha}^{-1}$ ) and benefit: cost ratio (1.53 and 1.45) was found under treatment having $100 \%$, NPK +5 t pressmud.

\section{REFERENCES}

Anonymous (2015-2016). Annual Report, Department of Agriculture, Cooperation and Farmers' Welfare, Ministry of Agriculture and Farmers Welfare, Govt. of India, Retrieved November, 292016 from http:// agricoop.nic.in.

Ashok, V., Kumar, S. and Singh, R. P. (2105). Enhanced growth and yield of rice (Oryza sativa L.) and soil environment are mediated by enhanced availability of $\mathrm{N}$ and $\mathrm{P}$ in soil and plant leaves on application of organic matrix entrapper urea and DAP. International J. Plant and
Environment, DOI: 10.18811/ijpen.v1i1.7114.

Chesnin, L. and Yien, C. H. (1951).Turbidimetric determination of sulphur.Proc. Soil Sci. Soc. Amer. 15: 142-152.

Jackson, M.L. (1973). Soil chemical analysis, prentice hall of India Pvt. Ltd., New Delhi.

Jeyajothi, R. and Durairaj, S. N. (2016). Influence of integrated nutrient management practices on dry matter production, yield and NPK uptake of transplanted rice (Oryza sativa). J. Applied and Natural Science, 8(2): 574-578.

Kabaki, N. (1993). Growth and yield of Japonica-indica hybrid rice.Japan Agril. Res. 27: 87-94.

Kumar, N., Verma, L. P., Singh, R. and Prasad, K. (2001).Soil properties, nutrients uptake and productivity of rice under integrated nutrient management system.Ann Plant Soil Res. 3 (10): 54-57.

Lin, J. L. and Lin, T. L. (1985). Tiller number and leaf area index in rice community as influenced by planting density and nitrogen fertilizer. J Agric. Assoc. China129: 14-34.

Lindsey, M. L. and Norwell, W. A. (1978). Development of DTPA test for Zn, Fe, Mn and Cu. Soil Sci. Soc. Amer. J.42: $421-428$

Parasuraman, P. (2005). Integrated nitrogen management in rice (Oryza sativa) through split application of fertilizers at different levels with green manure. Mysore J. Agri. Sci., 39 (1): 90-94.

Prabakaran, K. and Sivapragasam, C. (2014).Forecasting areas and production of rice in India using ARIMA model.Int. J. Farm Sci. 4(1): 99-106.

Rabeya, Khaman.; Sahu, S.K. and Mitra, G.N. (1997). Yield maximisation of rice through integrated nutrient management on aeric ustochrept. J. Indian Soc. Soil Sci., 45 (2) : 346-397.

Reddy, S. R. (2000).Sustainable agriculture, Prince of Agron.Kalyani Publishers, New Delhi, 449-458.

Sharma, S.K. and Sharma, S.N. (2002). Integrated nutrient management for sustainability of rice (Oryza sativa) wheat (Triticum aestivum) cropping system. Indian $J$. Agri. Sci., 72 (10) : 573-576.

Singh, A. K. (2013). Impact of integrated nutrient management on growth parameters, physiological characteristics, yield and yield attributes of hybrid rice. J Soil Crops, 23(2): 259-263.

Singh, A. K. (2014 a). Soil fertility, yield and nutrient uptake of hybrid rice as influenced by integrated nutrient management. Adv. Plant Sci. 27 (1): 189-192.

Singh, A. K., Chandra, N. and Bharti, R. C. (2012).Effect of genotype and planting time phenology and performance of rice (Oryza sativa L.).Vegetos 25(1): 151-156.

Singh, A. K., Manibhushan, Chandra, N. and Bharti, R. C. (2008).Suitable crop varieties for limited irrigated conditions in different agro-climatic zones of India.Int. J.Trop. Agri. 26 (3-4): 591-496.

Singh, A. K., Singh, A. K. and Kumar, A. (2014 b).Quality parameters, harvest index of hybrid rice (Oryza sativa L.) and economics of various treatments under various levels of zinc sulphate and integrated nutrient management. Int. J Agric. Sci. 5 (2): 137-144.

Snedecor, G.W. and Cochran, W.G. 1967. Statistical method $6^{\text {th }}$ Edn. Oxford and IBH Publishing Corp. Calcutta. 
Ashish Kumar Srivastava and Anil Kumar Singh / J. Appl. \& Nat. Sci. 9 (4): 2414 - 2420 (2017)

Swaroopa, V.J., Mounica, D. and Pavani, U. (2016). Impact of frontline demonstrations on paddy variety MTU1075 in tribal areas of East Godavari district of Andhra Pradesh. Int. J. Farm Sci. 6 (3):12-16.

Thukral, B.R., Singh, R., Mishra, K.K. and Jaiswal, H.R. (1994). Effect of plant growth regulators on growth and mineral composition of leaves of lemon (Citrus lemon burn) Ann. Agric. Res. 15(3): 306-309.
Yamauchi, M. (1994).Physiological basis of higher yield potential in F-1 hybrid. JRRN: 71-80.

Young, Zian Chang; Su, Bao Lin; Wang, Zhi Qin; Long, You Zhong; Zhu, Qing, Sen; Yang, J.C., Su, B.L.; Wang, Z.Q.1 Long, Y.Z.; Zhu, A.S. and Lu, FelJia (1999). Characteristics and physiology of grain filling in inter sub specific hybrid rice, Chinese Agril. Sci.,61-70 